\title{
SOLID WASTE MANAGEMENT AT AN INTERNATIONAL FULL-MARATHON RUNNING EVENT IN SOUTHERN THAILAND
}

\author{
SINEENART PUANGMANEE \& MALIK SAEARLEE \\ Faculty of Science and Technology, Phuket Rajabhat University, Thailand
}

\begin{abstract}
Marathon running is the most popular sporting event in the world. Therefore, marathon solid waste is an important aspect of these events. Many activities that support the runners produce much waste, which is difficult to control and manage. This paper aimed to study marathon solid waste management at an international full-marathon running event, along with the support activities. The data included the types and volumes of waste in addition to waste storage, collection, transfer, and disposal. The sample site was an international full-marathon event in southern Thailand. Two groups of activities were identified. The first group included 11 activities at service points directly concerned with the runners. The second group included two activities not related with marathon running, i.e. an expo zone and food zone. All waste was classified into general waste, compostable waste, recyclable waste, and hazardous waste for each group activity. The total amount of waste from all activities was $2,702.70 \mathrm{~kg}$, that included $2,527.20 \mathrm{~kg}$ and $175.50 \mathrm{~kg}$ that were related and unrelated to marathon running, respectively. Moreover, it was noted that unsuitable protective equipment was worn by the workers. Some containers and vehicles did not follow the guidelines according to the laws; however, the government allowed them to work. A waste recycling facility received $458.10 \mathrm{~kg}$ of recyclable waste. General waste, compostable waste, and hazardous waste $(2,244.60 \mathrm{~kg})$ were transferred without separation for disposal by incineration. Although the organizers tried to control and manage the waste at the event, some of the waste handling procedures were incorrect and ineffective. In conclusion, the organizers and participants need greater awareness of eco-friendliness for an eco-marathon.
\end{abstract}

Keywords: international full-marathon running event, marathon running, solid waste management.

\section{INTRODUCTION}

Recently, most people exercise frequently and play sports. One sport that is the most popular is marathon running. Many marathon running events at the local, national, and international level are conducted worldwide. Some running events are world famous, such as the London Marathon, BMW-Berlin Marathon, Boston Marathon, Chicago Marathon, New York City Marathon, and Tokyo Marathon [1]. It is a challenge, especially for runners who want to beat the previous records. Normally, a running event includes the organizers and the owners of the running area who organize and manage the event to support the runners and spectators. All of these events produce waste as a result of the event. During the event, waste is scattered in the area of the event and along the running route which can be an ugly sight. In addition, waste from food, packages, and goodie bags get left behind by the spectators and runners [2]. In the Boston Marathon of 2017, 1.4 million paper cups were distributed to the runners and 171,380 paper brochures and visitor's guides were printed [3]. In the London Marathon of 2018, the Westminster City Council collected 5,200 kg of rubbish and 3,500 kg of materials for recycling that included 47,000 plastic bottles from the street [2]. Moreover, some international marathons do not control or manage the waste correctly even though they are aware of the environmental impact from the event.

Thailand has many marathons at both the local and national levels that produce a lot of waste. Therefore, we aimed to study waste management at an international full-marathon running event in southern Thailand and collect data on the support activities, running 
matches, types and quantities of waste, the storage, collection, and transfer/transport of the waste, and the disposal of solid waste materials.

\section{METHODOLOGY}

This survey research focused on solid waste management at an international full-marathon running event (IFmRE) that was set in southern Thailand. IFmRE replaces the true name of the marathon running event to protect the identity. This event is the biggest marathon in South-East Asia, and meets the highest international standard that is also the qualifier for the Boston Marathon. The event is professionally scheduled by Sportstats Asia and it is certified by the Association of International Marathons and Distance Races.

\subsection{Area site}

The IFmRE was set in a district of Phuket Island in southern Thailand. The number of runners exceeded 13,000 participants from more than 50 countries and took place during 7-9 June 2019.

\subsection{Survey method}

\subsubsection{Surveys and interviews}

Surveys and interviews were conducted with the organizer, the owner of the area for the marathon, and employees to determine the overall format of the running event, the related and unrelated activities of the running events, and the waste management of the IFmRE. This study documents the types and quantities of waste and the storage and collection of waste in terms of containers, employees, and equipment. Also studied were the transfer/transport and disposal in terms of employees, periods of time for transfer/transport, equipment, vehicles used, and the disposal site.

\subsubsection{Sampling frames}

The types and quantities of the IFmRE waste (IFmREW) were studied by sort segregation and the waste was weighed from all activities of the marathon that covered three running matches that consisted of a half-marathon $(21.0975 \mathrm{~km})$, marathon $(42.195 \mathrm{~km})$, and marathon relay $(42.195 \mathrm{~km})$. On 9 June 2019, the number of runners was around 7,304 people. The waste was collected from 04:00 a.m. to 12:00 p.m. The IFmREW that was collected included waste related directly to the running event and waste that was unrelated to the running event.

\section{RESULTS AND DISCUSSION}

The results of this article describe the activities and running matches, types and quantities of waste, waste storage and collection, and waste transfer/transport and disposal at the IFmRE.

\subsection{Marathon running event activities}

A total of 13 activities produced waste materials. Eleven activities produced waste that was directly related to the running event (IRFmRE) and two activities produced waste that was unrelated to the event (IUFmRE) (Table 1). 
Table 1: Activities and sources of waste.

\begin{tabular}{|c|c|c|}
\hline No. & \multicolumn{2}{|c|}{$\begin{array}{l}\text { Activities and sources of waste } \\
\end{array}$} \\
\hline \multirow[t]{11}{*}{1} & \multirow{11}{*}{$\begin{array}{l}\text { International related } \\
\text { full-marathon running } \\
\text { event (IRFmRE) }\end{array}$} & 1.1 Souvenir service point \\
\hline & & 1.2 Water service point \\
\hline & & 1.3 Relaxing massage service point \\
\hline & & 1.4 Food service point for runner \\
\hline & & $1.5 \mathrm{Start} / \mathrm{stop}$ point \\
\hline & & 1.6 Sponsor service point \\
\hline & & 1.7 Winner register point \\
\hline & & 1.8 First aid point \\
\hline & & 1.9 Luggage drop-off service point \\
\hline & & $\begin{array}{l}1.10 \text { Water service point along the running route } \\
\text { (running route was used in } 3 \text { running matches) }\end{array}$ \\
\hline & & 1.11 Toilet service point \\
\hline \multirow[t]{2}{*}{2} & \multirow{2}{*}{$\begin{array}{l}\text { International unrelated } \\
\text { full-marathon running } \\
\text { event (IUFmRE) }\end{array}$} & 2.1 Expo zone \\
\hline & & 2.2 Food zone \\
\hline
\end{tabular}

\subsection{Types and quantities of solid waste}

The total amount of waste was $2,702.70 \mathrm{~kg}$ which consisted of 2,527.20 kg of IRFmRE waste (IRFmREW) and $175.50 \mathrm{~kg}$ of IUFmRE waste (IUFmREW) (Fig. 1). The rate of waste based on the amount per person from all activities was $0.37 \mathrm{~kg} /$ person/day. The types and quantities of the waste were also categorized into four types: general waste, compostable waste, recyclable waste, and hazardous waste (Figs 2-4).

The amount of general IRFmREW was the greatest which consisted of paper (wax cups, bowls, and plates), sponges, and plastic bags. The results of paper cups (wax cups) were similar to reports by Mahmud [4] and Mervosh [5]. The compostable waste included coconuts, food waste, and fruit peelings from bananas and watermelons. The results of fruit waste materials were similar to a report by Mahmud [4] on the annual Singapore marathon and a report on the shrinking carbon footprint event at the Salzburg Marathon [6] where banana peels were found. In the category of recyclable waste, the amount of single-use water bottles was similar to the reports by Mahmud [4], Smithers [7], United Nations Environment Programme [8], Mervosh [5], Lewis [9], and Cheung [2]. The amount of single-use plastic cups was similar to the reports by the United Nations Environment Programme [8] and Lewis [9]. The amount of cardboard materials was similar to a report from the Monterey Bay Half Marathon [10]. Finally, the hazardous waste category found infectious waste materials, such as toilet rolls, Accu-Chek FastClix and absorbent cotton/paper contaminated with blood, masks, and medical plaster bandages. Toxic waste materials included containers of pain relief medicine for relief of muscular aches and pain in the forms of spray, cream, and gel, and bottles for $70 \%$ alcohol.

In the IUFmREW, general waste was the highest amount which included plastic bags, paper materials including wax cups, bowls, and plates, wet paper and wet cardboard, foam boxes, plastic spoons and boxes, and packs of energy gel. These materials were similar to the 
findings by Mahmud [4]. In the category of compostable waste, food materials were found and in the category of recyclable waste, single-use plastic bottles were found. These results were similar to those reported by Mahmud [4], Smithers [7], Mervosh [5], Lewis [9], and Cheung [2]. The amount of aluminum cans was similar to the report by Mahmud [4] and the amounts of glass bottles and single-use plastic cups were similar to the reports by the United Nations Environment Programme [8] and Lewis [9]. The amount of cardboard materials was similar to the Monterey Bay Half Marathon report [10]. The hazardous waste materials included spray bottles, batteries, and print cartridges (Fig. 2). The amounts of waste materials are illustrated in Figs 3 and 4.

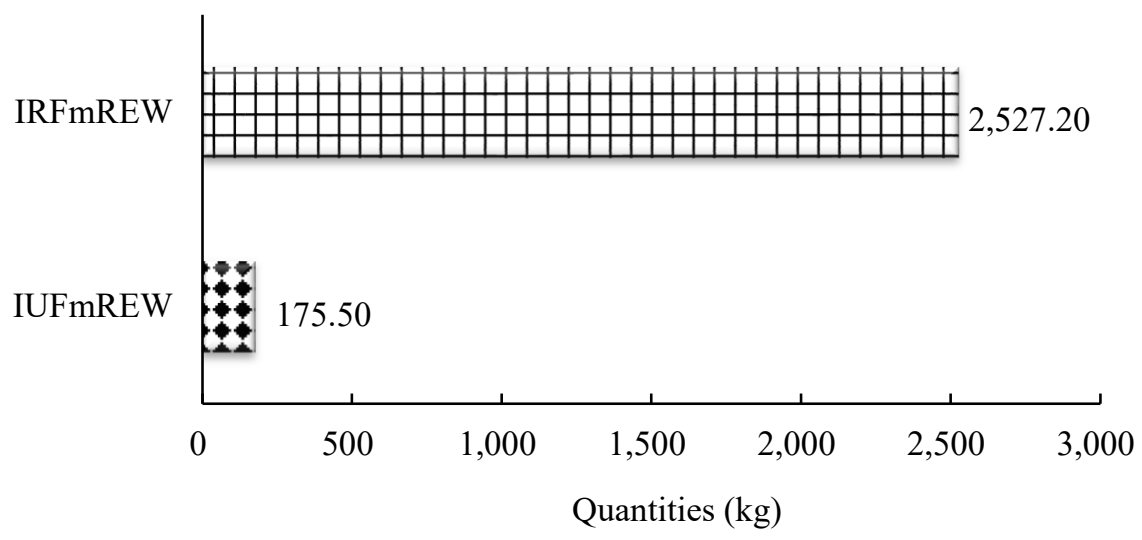

Figure 1: Types and quantities of IFmREW.

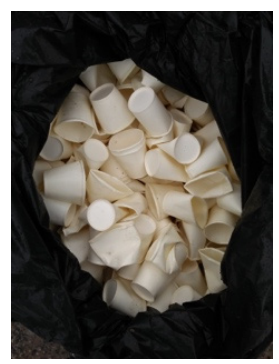

(a)

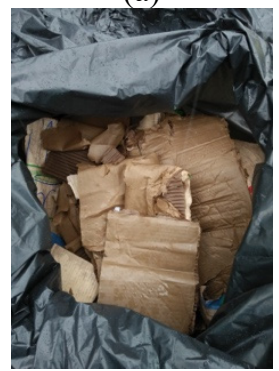

(e)

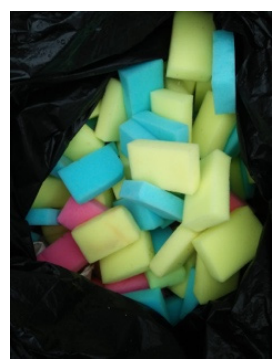

(b)

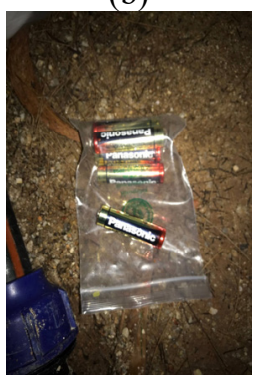

(f)

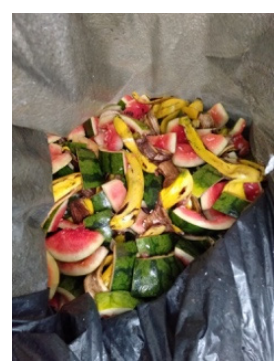

(c)

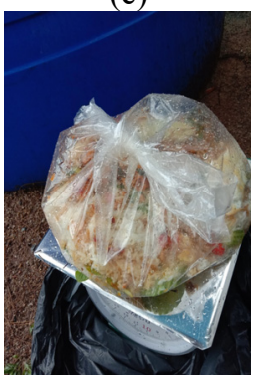

(g)

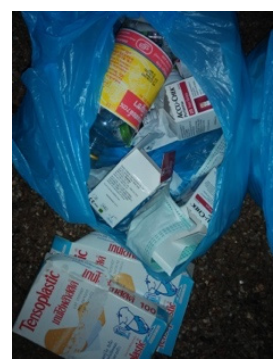

(d)

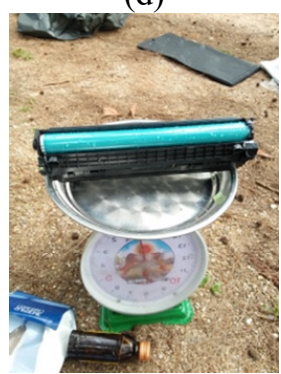

(h)

Figure 2: (a)-(d) Waste materials from IRFmREW; and (e)-(h) Waste from IUFmREW. 


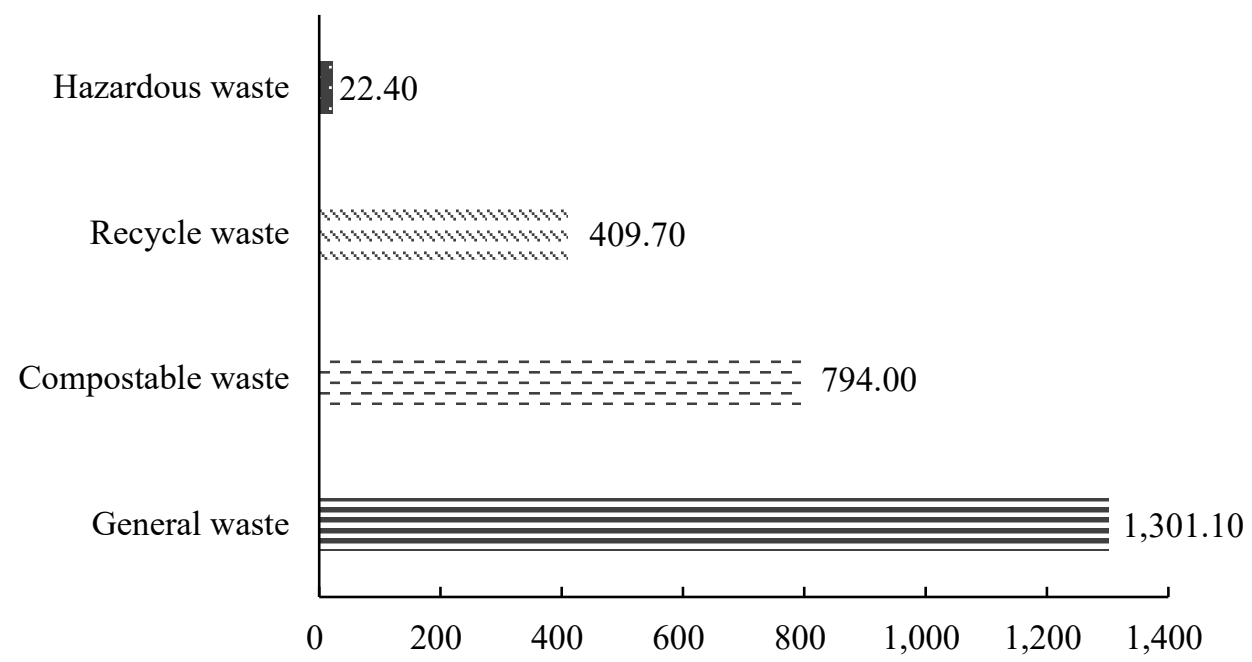

Quantities (kg)

Figure 3: Types and quantities of IRFmREW.

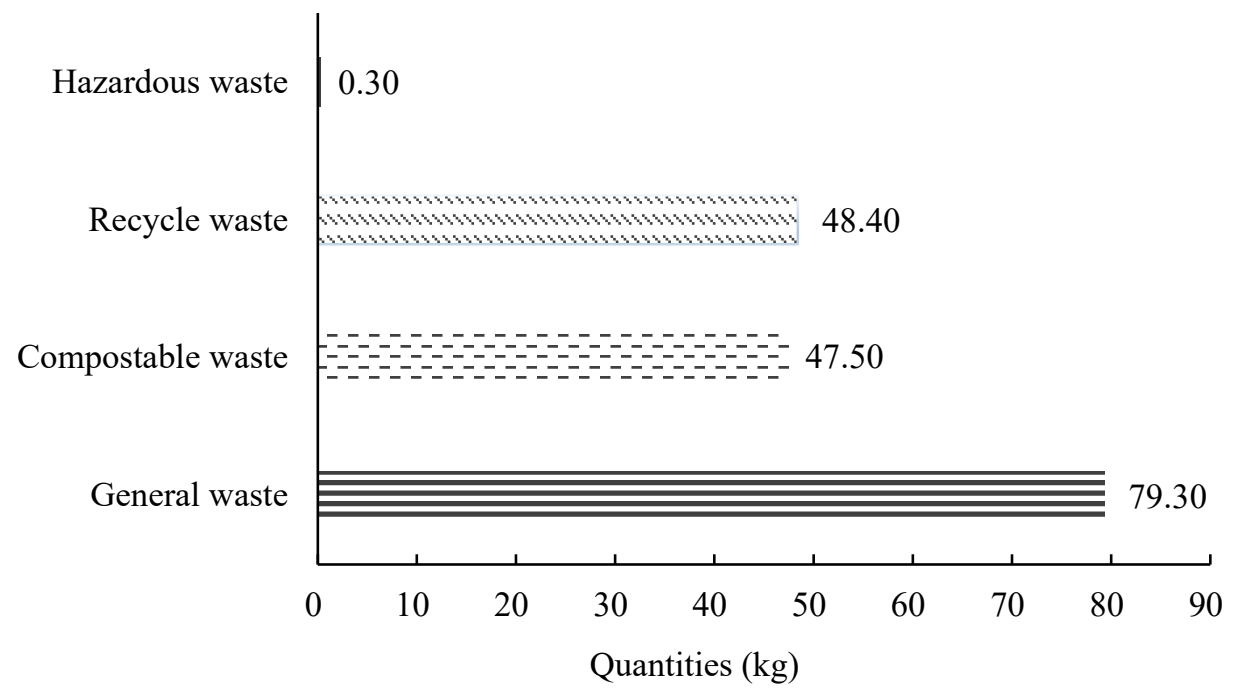

Figure 4: Types and quantities of IUFmREW.

Some waste at the marathon event was found to be separated at the sources for disposal at the end of pipe. These waste materials were separated into two types that consisted of general waste $(2,244.60 \mathrm{~kg})$, such as wet plastic materials (bags, boxes, bowls, and plates), wet paper materials (boxes, wax cups, plates, and bowls), foam (boxes, bowls, and plates), and recyclable waste $(458.10 \mathrm{~kg}$ ) that included clear plastic PET bottles, colored plastic bottles, and paper and cardboard materials (Fig. 5). 


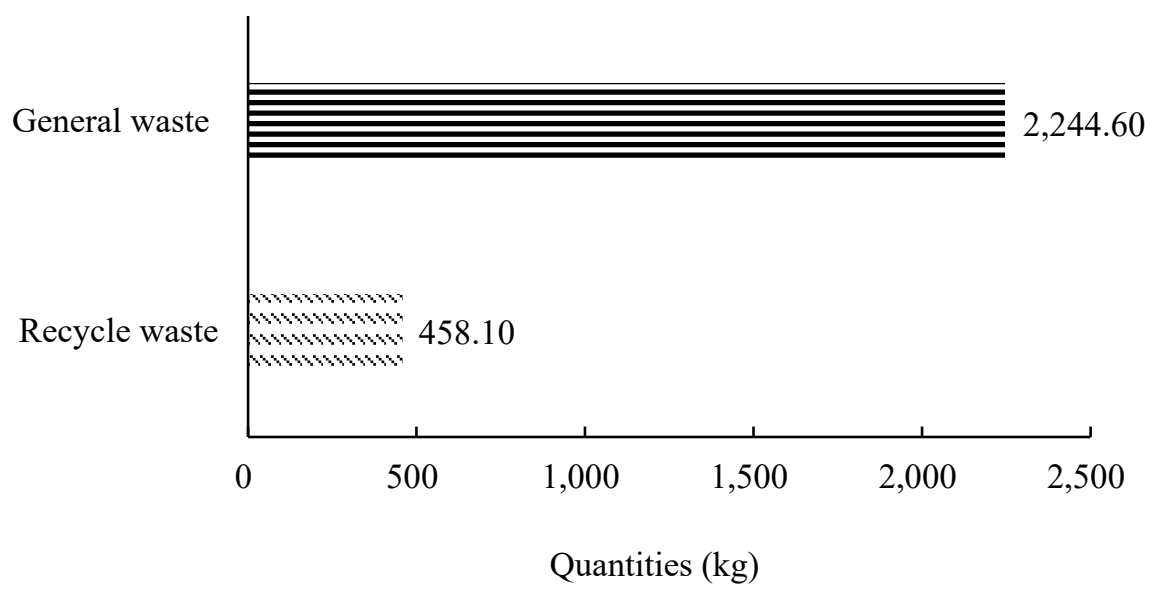

Figure 5: Types and quantities of IFmREW disposal.

\subsection{Waste storage and collection}

Most waste materials were not separated at the source. The various waste materials were deposited together into black plastic bags that were placed inside steel frames, plastic buckets, or baskets (Fig. 6). Waste materials at some points were separated by waste workers at the sources into the two types of general waste and recyclable waste for easier disposal at the end. All waste materials from the running event were moved to temporary waste storage areas: Storage 1 and Storage 2.

At Storage 1, the waste was collected from souvenir service points, food service points for the runners, winner registration point, first aid points, luggage drop-off service points, toilet service points, and waste from the running route. At Storage 2, waste was collected from the water service points, relaxing and massage service points, start/stop points, sponsor service points, and food zones. Storage 1 and Storage 2 areas were unsuitable according to the laws because they were not buildings and did not have roofs for protection from rain in the event of rainfall. The two storage areas were simple stalls in an area near the activities zone.

In each of the storage areas, the waste materials were combined and classified by workers for separation into two kinds of waste: general waste destined for an incinerator and recyclable waste destined for a recycling shop.

The waste workers who collected the waste can be classified into three groups: 12 employees employed from an outsourced company; five employees (garden department workers) of the owner of the marathon event area; and three temporary workers that the owner of the marathon running event area employed for waste collection. Seventeen workers kept the waste from all activities within the running event area, except the running route. The three temporary workers collected the waste and moved it from the running route by local vehicle. They then moved all of the waste materials to the two temporary waste storage points and waited for transfer of the waste to a disposal site around two days later.

While working, they wore unsuitable personal protective equipment. They did not wear health masks, gloves, rubber boots, plastic apron, medical caps, or eye goggles (Fig. 7). These practices were in conflict with the Ministerial Regulation on General Waste Management B.E. 2560 (2017) [11]. 


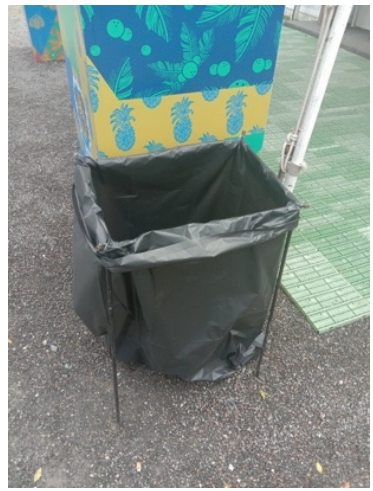

(a)

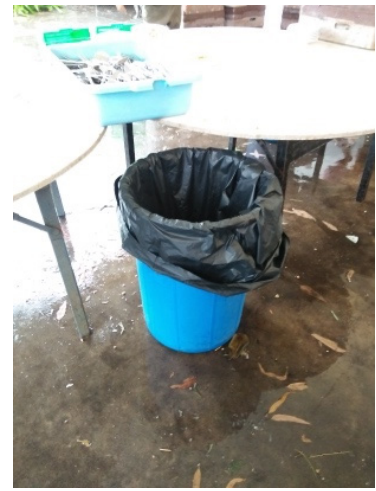

(b)

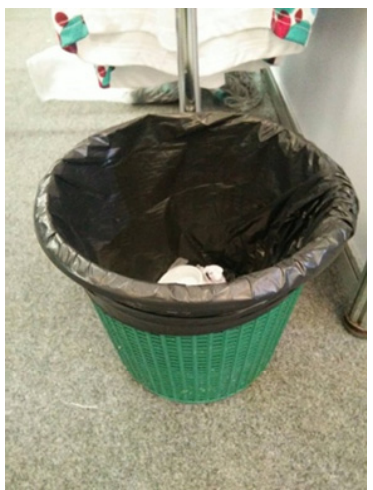

(c)

Figure 6: Containers of waste. (a) Steel frame for hanging black plastic garbage bag; (b) Plastic bucket with black plastic bag; and (c) Basket with black plastic bag.
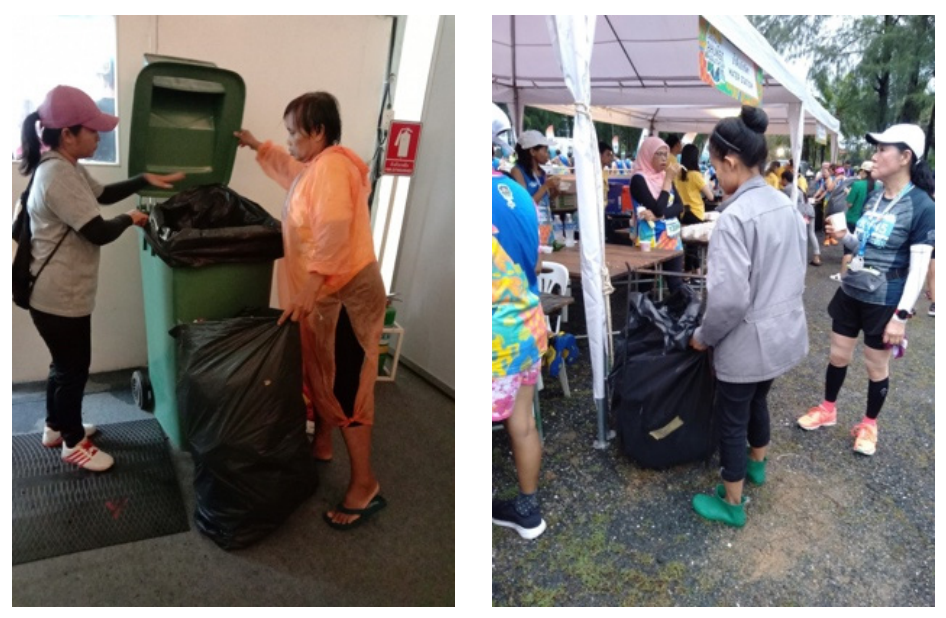

Figure 7: Personal protection equipment suits of the waste workers.

\subsection{Waste transfer/transport and disposal}

The waste materials at the two storage points remained there for around two days. The general waste and recyclable waste were then transported for disposal by six employees from a private company sanctioned by the government. They moved the waste materials using two pickup trucks following the completion of the running event. The local vehicles and pickup trucks were in conflict with the guideline (Fig. 8) [11] because the vehicles were unsuitable for hauling waste materials because they could leak, spill, or allow the waste to fly away during transfer and transport which would contaminate the environment. According to law, the vehicles must be made from a durable material and structure that is easily cleanable and can be closed to prevent waste from leaking and flying away from the transport vehicle. At the end of the process, the waste materials were transported for disposal at an incinerator or to a recycling center. 


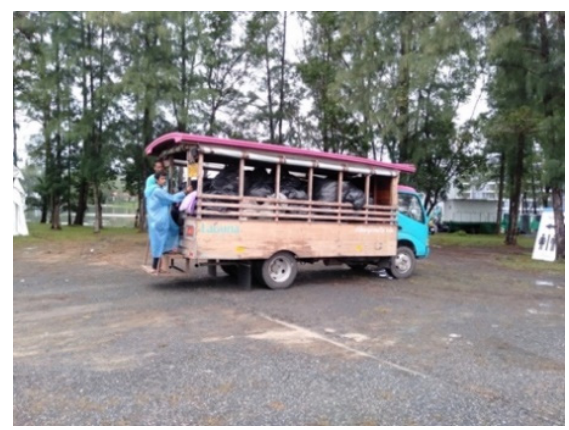

(a)

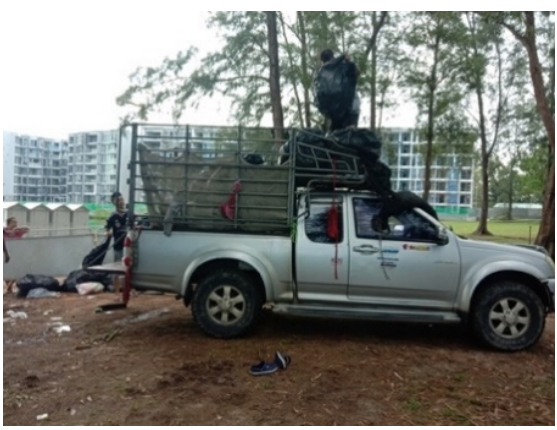

(b)

Figure 8: Waste transfer and transport vehicles. (a) Local vehicles move waste from running route; and (b) The pickup truck moves waste to disposal.

The general waste materials were moved to an incinerator plant and the recyclable waste was transported to a recycling shop that met the requirements of the Ministerial Regulation on General Waste Management B.E. 2560 (2017) [11]. The disposal recycling methods were similar to reports from the AACR Philadelphia Marathon 2017 [12], Swiss City Marathon 2018 [13], Monterey Bay Half Marathon 2017 [10], BMW Berlin Marathon 2019 [14], Sanlam Cape Town Marathon 2019 [13], and the London Marathon 2019 [15]. The Philadelphia Marathon disposed waste by recycling, donation, and landfill, the Swiss City Marathon disposed waste by recycling, the Monterey Bay Half Marathon disposed waste by recycling, composting, donating, and landfill, the BMW Berlin Marathon put the waste into recycling processes using normal recycling and thermal recycling (energy-from-waste), and donating, the Sanlam Cape Town Marathon disposed waste by recycling or composting, and the London Marathon used recycling for disposal of the waste.

The waste disposal flow chart of the IFmREW is shown in Fig. 9. Overall, the waste materials were not separated. In fact, these waste materials could have been separated at all points for easy classification of the waste for disposal. The organizer should put specifically labeled and suitable containers for depositing the waste according to the type of waste for easy handling before transfer to the temporary waste Storage 1 and Storage 2. Some waste at some points in the storage areas were separated into recyclable waste and general waste and was mixed with compostable and hazardous materials. The waste materials were transferred and transported for disposal at a recycling shop or incinerator using pickup trucks. The methods used for waste disposal followed the laws but the vehicles were in conflict with the laws. In addition, all waste materials were produced by the main organizer and sponsors. If they are aware of the environmental impact, they must control and manage the waste at each activity at the sources with the concept of reduce, reuse, and recycle.

We have these suggestions.

1. Change and reduce some types of containers for food and drinks. All single-use plastic and foam items, such as plastic spoons, plastic boxes, wax cups, plastic bottles, and plastic cups should be replaced with compostable or biodegradable cups made from maize straw. Plastic bottles should be made from $100 \%$ or $50 \%$ recycled plastic and reduce the unrecyclable plastic packaging for food and drinks. 
2. Change and reduce some types of fruits since some fruits are difficult to destroy and are not compostable, e.g., coconuts. Coconuts should not be available or the supply of coconuts should be greatly reduced.

3. Add more types of containers for the depositing of waste and use at least 4 types, i.e. general waste, compostable waste, recyclable waste, and hazardous waste for separation of the waste at the source site.

4. Separate the waste for suitable disposal, i.e. recycling, compost, donation, landfill, and incineration.

5. The temporary waste storage facility should be a durable structure with a roof to protect the waste from rainwater. When waste materials become wet, they can produce a leachate that contaminates the soil, reservoirs, and streets during waste transfer/transport. Also, some wet recyclable waste materials cannot be moved to a recycling center.

6. The waste handlers need to wear suitable personal protective equipment according to the guideline.

Finally, the vehicles for waste transfer/transport should be suitable and meet the requirements according to the law.

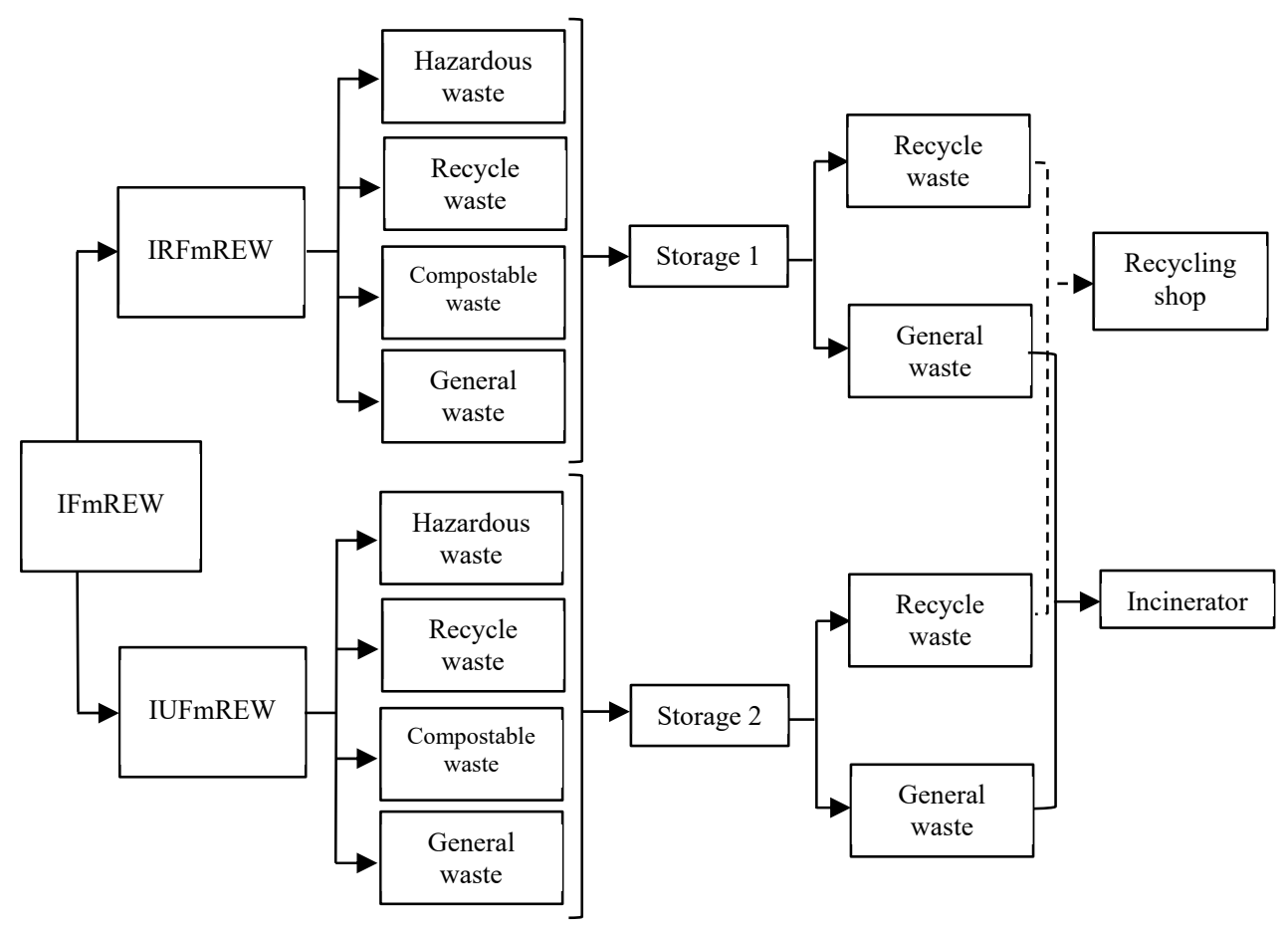

Figure 9: Waste disposal flow chart of IFmREW.

\section{CONCLUSIONS}

The IFmREW were separated into two types of waste. (1) IRFmREW included hazardous waste, recyclable waste, compostable waste, and general waste. The main sources of waste were from 11 activities (souvenir service points, water service points, relaxing massage 
service points, food service points for the runners, start/stop points, sponsor service points, winner register point, first aid points, luggage drop-off service point, water service points along the running route, and toilet service points. (2) IUFmREW included hazardous waste, recycle waste, compostable waste, and general waste. The main sources of waste were from the expo and food zones. The proportion of IRFmREW was much greater than IUFmREW. The waste storage points and collection were improper. The personal protective equipment of the waste workers was unsuitable and vehicles used for the transfer and transport of the waste materials were in conflict with the guideline. The practices of using an incineration plant for general waste and recycling shops for recyclable waste were lawful according to the laws of Thailand. Even though an international full-marathon running event is conducted over a short period of time, it can produce much waste. The organizer, sponsors, owner of the running event area, runners, and participants need to be aware of the impact on the environment and use positive measures to protect the ecosystem.

\section{ACKNOWLEDGEMENT}

The authors would like to thank Phuket Rajabhat University for their financial support for the registration and carfare.

\section{REFERENCES}

[1] Abbott World Marathon Majors. www.worldmarathonmajors.com. Accessed on: 12 Feb. 2020.

[2] Cheung, H., London Marathon: How do you reduce the environmental impact? 2019. www.bbc.com/news/science-environment-48064102. Accessed on: 10 Feb. 2020.

[3] How to stay eco-conscious during the Boston marathon. https://tataandhoward.com/ stay-eco-conscioys-during-boston-marathon/. Accessed on: 12 Feb 2020.

[4] Mahmud, A.Z., See the number of cups thrown: Can the waste produced during marathons be reduced? 2018. www.channelnewsasia.com/news/singapore/wste/ produced-marathons-runs-races-organisers-go-green-10257948. Accessed on: 19 Nov. 2019.

[5] Mervosh, S., Seaweed pods, anyone? Marathons get creative to stop littering the streets, 2019. www.nytimes.com/2019/04/30/sports/marathons-plastic-water-bottles. html?utm_source=headtopics\&utm_medium=new\&utm_campaign=2019-04-30. Accessed on: 10 Jan. 2020.

[6] Marathon running's shrinking footprint event, Salzburg marathon, 2019. www.continental-tires.com/car/about-us/media-services/gripworld/events/2019-0520-fussabdruck. Accessed on: 10 Feb. 2020.

[7] Smithers, R., Single use plastics bottles banned from half marathon in London, 2018. www.theguardian.com/environment/2018/sep/12/single-use-plastic-bottles-bannedfrom-half-marathon-in-london. Accessed on: 10 Jan. 2020.

[8] United Nations Environment Programme, Xiamen marathon runs towards plastic-free future with \#CleanSeas, 2018. www.unenvironment.org/news-and-stories/pressrelease/xiamen-marathon-runs-towards-plastic-free-future-cleanseas. Accessed on: 19 Jun. 2019.

[9] Lewis, S., Thousands of seaweed pods will replace single-use plastic at the London Marathon, 2019. www.cbsnews.com/news/london-marathon-thousands-of-seaweedpods-willreplace-single-use-plastics/. Accessed on: 10 Dec. 2019.

[10] Montery Bay Half Marathon, Zero-waste-event, 2017. www.monterybayhalfmarathon.org/zero-waste-event/. Accessed on: 3 Feb. 2020. 
[11] Ministerial Regulation, General waste management B.E 2560. http://laws.anamai.moph.go.th/ewtadmin/ewt/laws/main.php?filename=2RLaws. Accessed on: 10 Dec. 2019.

[12] AACR Philadelphia marathon, Green Initiatives, 2017. www.philadelphiamarathon.com/info/green-initiatives. Accessed on: 8 Feb. 2020.

[13] Marathon running's shrinking footprint event, Swiss city marathon and Sanlam Cape Town Marathon, 2019. www.continaental-tires.com/car/about-us/media-services/ gripworld/events/2019-5-20-fussabdruck. Accessed on: 10 Nov. 2019.

[14] Marathon running's shrinking footprint event, Swiss City marathon and Sanlam Cape Town Marathon, 2019. www.continaental-tires.com/car/about-us/media-services/ gripworld/events/2019-5-20-fussabdruck. Accessed on: 10 Nov. 2019.

[15] Kottasova, I., Seaweed pouches will replace thousands of plastic bottles at the London marathon, 2019. https://edition.cnn.com/2019/04/26/business/london-marathonseaweed-water-bottles/index.html. Accessed on: 8 Feb. 2020. 